\title{
エネルギー入力に着目した実大震動破壊実験施設性能確認試験の評価 EVALUATION OF PERFORMANCE CHECK ON E-DEFENSE BASED ON THE ENERGY INPUT
}

\author{
山田＼cjkstart哲*1，前澤将男*2，森＼cjkstart利 弘*3 \\ 島田侑子*4, 佐藤栄児*5, 秋山宏*6 \\ Satoshi YAMADA, Masao MAEZAWA, Toshihiro MORI, \\ Yuko SHIMADA, Eiji SATO and Hiroshi AKIYAMA
}

\begin{abstract}
In the shaking table test, if force that acts on the specimen and energy input to the specimen can be measured from control information, it becomes powerful information to verify the measurement result. In this study, whether force and energy input by control information were able to be measured at E-defense was examined. The maximum value of force was able to be measured by control information. However, in time history, unbalance caused by the incompleteness of modeling of the actuators was contained. Therefore, energy input was not able to be measured from control information. Moreover, the influence of the rotation of the table on the experimental result was significant. It is necessary to develop the control method of making the rotation of the table minimum.
\end{abstract}

Keywords: E-Defense, Energy Input, Performance Check, Shaking Table E-ディフェンス, エネルギー入力, 性能確認試験, 振動台

\section{1.はじめに}

1995 年 1 月 17 日未明に発生した兵庫県南部地震での甚大な被害 を受け、地震下における構造物の動的挙動ならびに破壊過程を解明 し、構造物の耐震性向上と耐震補強技術を確立するため、(独)防災 科学技術研究所により世界最大級の実大三次元震動破壊実験施設 (E-ディフェンス)が建設された。(振動台一般を表す場合には振動台、 E-ディフェンスの大型振動台のみを表す場合には震動台と表記す る。)この震動台は、実大規模の構造物の破壊実験を可能にする世 界最大級の実験装置であり、各種構造物の動的破壊実験を通じて耐 震工学の進歩に寄与することが期待されている。

大型構造物の振動台実験を行う場合、計測項目が膨大になり、実 験結果の全体像を如何に総合的に捉えるかが問題となる。本研究で は、試験体へのエネルギー入力に着目する。試験体へのエネルギー 入力は、エネルギーの授受に着目した耐震設計"における総合的な 評価指標であるだけでなく、試験体に作用した力とそれにより生じ た変形の積分值として、実験結果を評価する上でも有効な指標であ る。試験体へのエネルギー入力を、試験体の計測ではなく振動台の 制御情報から計測することができれば、加振情報として実験結果を 捉えることができるだけでなく、エネルギー入力を計測する過程で 試験体に作用する力を試験機側から計測することになるので、計測
結果を検証する上で非常に有力な情報となる。

試験体へのエネルギー入力を制御情報から計測する研究は、既に 多度津の振動台について行われており 2)、摩擦力による消費エネル ギーを適切に評価することでエネルギー入力が求まることが報告さ れている。実大三次元震動破壊実験施設(E-ディフェンス)において も震動台制御情報による試験体へのエネルギー入力を計測すること を主目的とし、実験での運用に先立ち行われた性能確認試験結果を 用いて検討を行う。

本論文では、最初に制御情報に含まれる加振機の圧力情報から加 振力を求め、これを用いて試験体に作用した力とモーメントを求め、 試験体側での計測結果と比較検討する。これは、E-ディフェンスに おける制御情報には震動台の変位・回転角に関する情報が含まれて いるものの、試験体に作用したカ・モーメントに関する情報は含ま れていないことによる。ついで、制御情報と試験体側での計測結果 の双方に基づき求めた試験体へのエネルギー入力を比較し、制御情 報からエネルギー入力を計測することができるかを検討する。また、 本研究では試験体へのエネルギー入力に着目していることから、震 動台制御手法の違いにより実験にどのような影響が出たかについて も、試験体へのエネルギー入力の観点から検討を行う。
*1 東京工業大学統合研究院 助教授・博士 (工学)

*2 元東京工業大学 大学院生・修士 (工学)

*3 熊谷組技術研究所, 元防災科学技術研究所

*4 東京工業大学 大学院生

*5 防災科学技術研究所

*6 日本大学総合研究所 教授.工博
Assoc. Prof., Integrated Research Institute, Tokyo Institute of Technology, Dr. Eng. Former Graduate Student, Tokyo Institute of Technology, M. Eng. KUMAGAI GUMI CO., LTD., Former NIED

Graduate Student, Tokyo Institute of Technology

NIED

Prof., Nihon Univ., Dr. Eng. 


\section{2. 性能確認試験の概要}

\section{1 性能確認試験の目的}

本題であるエネルギー入力の計測の前に、本研究での検討対象と する震動台の性能確認試験について概説する。一般に構造物の振動 破壊実験では、その破壊過程を解明するために振動台上で再現され る波形は高精度に実現されることが望まれ、また適切に構造物を振 動させる必要がある。E-ディフェンスはテーブルの質量 775ton に 対し、搭載できる試験体の質量は最大 1200ton と、テーブルの約 1.5 倍の質量が搭載可能である。しかし、大規模な試験体を搭載した場 合には、試験体を搭載しない場合と比べ加振機にかかる負荷が大き く異なるため、台上で再現される波形の精度に影響がでることが䅗 念される。そこで E-ディフェンスでの本格的な振動破壊実験に備 え、試験体を適切に加振することができるかどうかの確認と台上で の波形再現性能等を確認するため、質量約 600ton の負荷試験体を 搭載し、性能確認試験を行った。

\section{2 試験体}

試験体は図1に示す 5 階建の鋼構造骨組であり、柱は円形鋼管、 梁は両端部を拡幅した $\mathrm{H}$ 形断面部材で、梁通しの接合となってい る。また、 X 方向(短手方向)には座屈拘束ブレースが組み込まれて いるが、Y 方向(長手方向)は純ラーメンである。ランダム加振結果 から求めた試験体の固有周期を表1に示す。

\section{3 パラメーター}

性能確認試験におけるパラメーターは制御方法、入力波、入カレ ベルである。まず最も重要なパラメーターである制御方法であるが、 E-ディフェンスの制御方法は加速度、速度、変位信号によるフィー ドバックおよびフィードフォワード制御(Three Variable Control)を 基本とした基本制御と、加振精度を高めるためのこれに付加的に追 加する複数の态用制御からなる。代表的な态用制御として繰り返し 入力補傥（以下、入力補傥）があるが、これは試験体と震動台の特 性をあらかじめ同定しておき、その特性から震動台上で目標とされ る波形が再現できるように入力波を補正する手法である。入力補偵 は以下の手順で実施される。

(1) 試験体が搭載された震動台の伝達関数を同定し、その結果から 逆伝達関数を求める。， (2) 求めた逆伝達関数に目標とする波形を 入力し、補償波形を作成する。（3) 作成した補償波形を震動台に 入力し、震動台上の再現波形と目標波を比較し補償波を調整する。 $\rightarrow$ (4) (3)を繰り返し、目標とする波形に祳動台上の波形を近づける。

今回の試験では、基本制御のみの場合と入力補傥を付加した場合を 実施した。

次に、入力波であるが、正弦波の他兵庫県南部地震鷹取記録 ${ }^{3)}(3$ 次元) 同神戸海洋気象台記録 ${ }^{4}$ (3 次元)、1993 年釧路沖地震釧路気 象台記録強震観測記録 "(NS 成分のみの 1 次元を使用)の強震加速度 記録について、入カレベルを変化させて加振を行った。これらの波 の中で釧路気象台記録を除くものは試験体を弾性に留める弾性加振 の入力波として用い、釧路気象台記録は試験体 1 階について座屈拘 束ブレースを強度を低くかつ両側の 2 構面のみに装着して塑性化さ せ、剛性変化の影響を調べる弹塑性加振の入力波として用いた。こ の理由は、図2に示す入力波(NS 成分)のエネルギースペクトル "か らわかるように、兵庫県南部地震の強震観測記録は試験体の 1 次固
有周期近傍でのエネルギー入力が小さく、1 階の座屈拘束ブレース を塑性化させることができないと判断したことによる。

\section{4 計測}

実験時に設置した加速度計、変位計、歪ゲージ等のセンサー類に よる計測(以下、試験体情報)と、震動台变位、回転角、加振機差圧 等の震動台制御情報(以下震動台情報)の 2 系統の合計約 1000 チャ ンネルの計測を、サンプリング周波数 $2000 \mathrm{~Hz}$ で行った。これらの 計測項目の中で本研究で用いたのは、

\section{(1)試験体情報について}

試験体各階に設置した加速度計による加速度記録

震動台上面に設置した加速度計による加速度記録

加振機バランスシリンダー差圧

(2)震動台情報について

震動台上面中央の変位・回転角

震動台上面中央の加速度・角加速度

加振機差圧

の各項目である。なお、両系統のデーターがアンプに収録されるま でに震動台情報は A/D,D/A 変換とフィルター処理が施されるため、 位相のずれが生じていた。この位相差は、A/D,D/A 変換による $1 \mathrm{msec}$ の時間ずれのほか、フィルター処理によって生じたものであるが、 フィルターの特性が明らかにされていないことから、両系統で共通 の計測を行った震動台上面中央における加速度記録の比較結果に基 づき、図3に示す8次の Butterworth フィルター(カットオフ周波数は $f c=100 \mathrm{~Hz}$ )であると推定した。1 msec の時間ずれと Butterworth フィ ルターによる位相ずれについて、補正前後の加速度の比較結果の例 を図4に示す。エネルギー入力の算定において試呀体情報と震動台 情報を混用する必要がある際は、上述の処理を計測値に施して震動 台情報と等しい位相特性を持つデーターとした。

\section{5 加振結果の概要}

弹性加振において神戸海洋気象台記録を原波の $50 \%$ の強さで入 カした際の、震動台上面中心位置に設置した加速度計の計測記録か ら速度応答スペクトル(减衰 $2 \%$ )を描き、制御目標波の速度応答ス ペクトル(减衰 2\%)と併せて図5に示す。基本制御の場合、水平動に ついては全体的に制御目標波に比べやや大きめの值となっている が、試験体 1 次固有周期付近では制御目標波をやや下回る結果とな っている。一方、入力補償制御の場合では、試験体 1 次固有周期付 近で制御目標波を上回る傾向が見られる。これは、転倒モーメント による影響と考えられる。試験体 1 次固有周期付近で目標通りの入 力となっているかどうかは、振動台実験において重要な点であるこ とから、今後制御方法の改善が望まれる。

震動台上面中心位置における 3 成分の加速度だけでは、転倒モー メントによって生じる回転の影響は捉えられないことから、弾性加 振において神戸海洋気象台記録を $50 \%$ の強さで入力した際の $\mathrm{x}$ 軸 周りの転倒モーメントの時刻歴を図6に、同じく震動台の $\mathrm{x}$ 軸周り の回転角の時刻歴を図7に、それぞれ基本制御で加振したときの結 果と入力補償制御で加振したときの結果を比較して示す。試験体が 弾性であり、同じ波を入力しているにも拘わらず、試験体の応答で ある転倒モーメントの時刻歴は制御方法で全く異なったものとなっ ている。同時刻の転倒モーメントと震動台の回転角を見ると、基本 
制御では転倒モーメントに合わせて回転角が生じているのに対し、 入力補償制御では基本制御の場合に生じる回転角と逆向きの回転が 生じており、制御が効き過ぎていることがわかる。転倒モーメント により生じる台の回転が実験に及ぼす影響については、論文後半に おいて試験体へのエネルギー入力の観点から論ずることとし、ここ では観察された現象を示すに留める。

\section{3. 震動台制御情報に基づくカの計測}

試験体に作用した力は、試験体へのエネルギー入力を評価するた めに必要な情報であるだけでなく、一般に振動台実験結果を評価す る上で重要な情報である。タンク内における液体のように実験中に おける試験体の質量分布が大きく変動し、かつ基礎部での力の計測 が困難な場合には、震動台情報から試験体に作用した力がわかれば 望ましいことは言うまでもないが、計測結果をキャリブレーション する場合や、加振時にセンサーに問題が発生した場合のバックアッ プとして、震動台情報から試験体に作用した力がわかることは重要 であり、実験装置として求められる機能である。ここでは、震動台 情報から求めた試験体に作用した力と試験体情報から求めた試験体 に作用した力を比較し、震動台情報に基づく力の計測結果について 検郡を行う。

カとモーメントの釣り合いを、図8に示す。震動台情報に基づく 震動台上面中央位置で試験体に作用するカとモーメントは、式(1) 〜 (6)で求まる。

$$
\begin{aligned}
& R_{x}{ }^{*}={ }_{a c} F_{x}-{ }_{T} m_{x} \cdot \ddot{T} \\
& R_{y}{ }^{*}={ }_{a c t} F_{y}-{ }_{T} m_{y} \cdot \ddot{T} \\
& R_{z}{ }^{*}={ }_{a c t} F_{z}-{ }_{T} m_{z} \cdot \ddot{T} \\
& M_{\theta x}{ }^{*}={ }_{a c} M_{\theta x}-\tau I \theta x \cdot r \ddot{\theta}_{x}-{ }_{\imath} m_{y} \cdot \ddot{T} \ddot{y} \cdot h_{z} \\
& M_{\theta y}{ }^{*}={ }_{a d} M_{\theta y}-{ }_{T} I_{\theta y} \cdot \ddot{\theta}_{y}+{ }_{T} m_{x} \cdot \ddot{T}_{T} \ddot{x} \cdot h_{z} \\
& M_{\theta z}{ }^{*}={ }_{a c} M_{\theta z}-{ }_{T} I_{\theta z} \cdot \ddot{\theta}_{T}-{ }_{T} m_{x} \cdot{ }_{T} \ddot{x} \cdot h_{y}+{ }_{T} m_{y} \cdot \ddot{y} \cdot h_{x}
\end{aligned}
$$

ここで、 ${ }_{a c t} F_{x, a c t} F_{y, a c t} F_{z}$ は $\mathrm{x}$ 方向, $\mathrm{y}$ 方向, $\mathrm{z}$ 方向の加振力であり、震動 台情報である各加振機の差圧から求まる加振力、同じく震動台情報 から求められるリンク材の回転角、そして上下方向加振機バランス シリンダーの保持力(震動台と試験体を試験位置に保持するために 必要な力であり、加振力を与えるのとは別のシリンダーにより与え られる)加、各方向成分の合力として算出した。ここで、加振機 の差圧から加振力を正確に求めるには加振機の剛性や内部減衰の影 響を正しく反映する必要があるが、後述するようにこれらの影響は 周波数毎に特性が異なりモデル化できなかったこと、さらには加振 機にロードセルが装着されておうらず加振力を求める方法が他に無か ったことから、次善の策として差圧から加振力を直接求めることと し、誤差については不釣り合いカとして評価することにした。また、 ${ }_{a a} M_{\theta x, a d} M_{\theta y, a \alpha} M_{\theta z}$ は $\mathrm{x}$ 軸周り, $\mathrm{y}$ 軸周り $\mathrm{z}$ 軸周りの加振モーメントであ り、加振力同様に算定した。 $\ddot{T}_{, T} \ddot{y}, \ddot{r} \ddot{z}$ は震動台可動部重心位置の $\mathrm{x}$ 方向,y 方向, $\mathrm{z}$ 方向の絶対加速度、 ${ }_{T} \ddot{\theta}_{x, T} \ddot{\theta}_{y, T} \ddot{\theta}_{z}$ は震動台可動部の $\mathrm{x}$ 軸 周り,y 軸周り, $\mathrm{z}$ 軸周りの角加速度であり、いずれも震動台情報であ る。そして、 ${ }^{2} m_{x, 7} m_{y, 7} m_{z}$ は震動台可動部質量、 ${ }^{2} l_{x x}, I_{\theta y}, I l_{\theta z}$ は震動台可 動部の重心まわりの回転慣性、 $h_{x}, h_{y}, h_{z}$ は震動台可動部重心のテーブ
ル上面中心からの距離であり、表2に示す値である。なお、式(1) (6) を構成する各項の中で、上下方向加振機バランスシリンダーの保持 力だけが震動台情報には含まれないことから、1 $\mathrm{msec}$ の時間ずれと Butterworth フィルターによる位相ずれの処理を行い震動台情報と 併せて使用した。

一方、試験体情報に基づく試験体に作用するカとモーメントは、 式(7)〜(12)で求まる。

$$
\begin{aligned}
& R_{x}=\sum_{i=1}^{6} m_{i} \cdot\left(\ddot{x}_{0}+\ddot{\theta}_{y 0} \cdot h_{i}+\ddot{x}_{i}\right) \\
& R_{y}=\sum_{i=1}^{6} m_{i} \cdot\left(\ddot{y}_{0}-\ddot{\theta}_{x 0} \cdot h_{i}+\ddot{y}_{i}\right) \\
& R_{z}=\sum_{i=1}^{6} s m_{i} \cdot\left(\ddot{z}_{0}+\ddot{z}_{i}\right) \\
& M_{\theta x}=\sum_{i=1}^{6} s I_{\theta x i} \cdot\left(\ddot{\theta}_{x 0}+\ddot{\theta}_{x i}\right)-\sum_{i=1}^{6} s m_{i} \cdot\left(\ddot{y}_{0}-\ddot{\theta}_{x 0}+\ddot{y}_{i}\right) \cdot h_{i} \\
& M_{\theta y}=\sum_{i=1}^{6} s I_{\theta y i} \cdot\left(\ddot{\theta}_{y 0}+\ddot{\theta}_{y i}\right)+\sum_{i=1}{ }_{s} m_{i} \cdot\left(\ddot{x}_{0}+\ddot{\theta}_{y 0}+\ddot{x}_{i}\right) \cdot h_{i} \\
& M_{\theta z}=\sum_{i=1}^{6} s I_{\theta z i} \cdot\left(\ddot{\theta}_{z 0}+\ddot{\theta}_{z i}\right)
\end{aligned}
$$

ここで、smiは RF を 6 階として構成部材を階高中央で上下階に分割

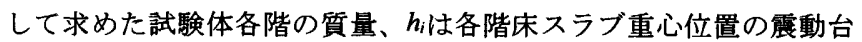

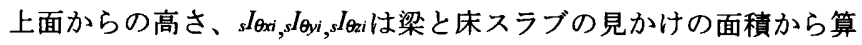
出した各階床スラブ重心周りの回転慣性であり、それぞれ表3に示 す值である。また、 $\ddot{x}_{0}, \ddot{y}_{0}, \ddot{z}_{0}$ 情震動台上面中心位置の各方向絶対加 速度、 $\ddot{\theta}_{x 0}, \ddot{\theta}_{y 0}, \ddot{\theta}_{z 0}$ は震動台上面中心位置における $\mathrm{x}$ 軸周り, $\mathrm{y}$ 軸周り, $\mathrm{z}$

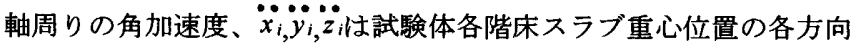
相対加速度、 $\ddot{\theta}_{x i} \ddot{\theta}_{y i} \ddot{\theta}_{z i}$ は試験体各階床スラブの $\mathrm{x}$ 軸周り, $\mathrm{y}$ 軸周り, $\mathrm{z}$ 軸周りの角加速度である。

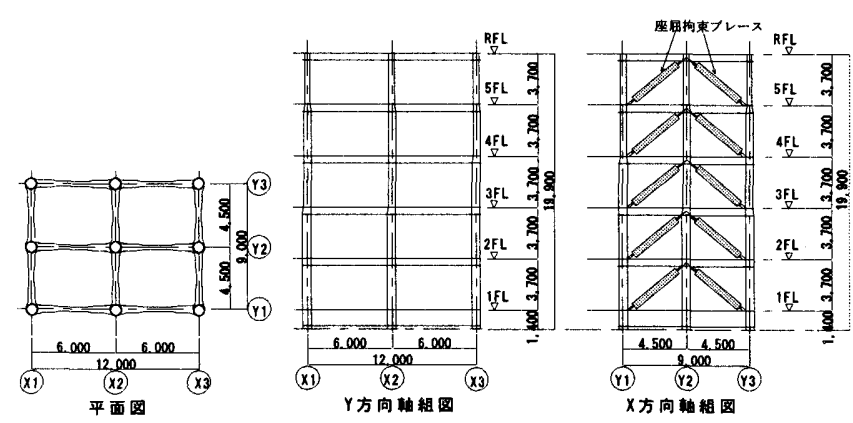

図1 試験体概要

表1 試験体の固有周期

\begin{tabular}{c|c|c|c|c|c|c}
\hline & $\begin{array}{c}x \\
(\mathrm{sec})\end{array}$ & $\begin{array}{c}y \\
(\mathrm{sec})\end{array}$ & $\begin{array}{c}z \\
(\mathrm{sec})\end{array}$ & $\begin{array}{c}\theta x \\
(\mathrm{sec})\end{array}$ & $\begin{array}{c}\theta y \\
(\mathrm{sec})\end{array}$ & $\begin{array}{c}\theta z \\
(\mathrm{sec})\end{array}$ \\
\hline 1次 & 0.185 & 0.333 & 0.058 & 0.051 & 0.196 & 0.161 \\
\hline 2次 & 0.065 & 0.118 & - & - & - & 0.058 \\
\hline 3次 & 0.037 & 0.067 & - & - & - & 0.036 \\
\hline
\end{tabular}




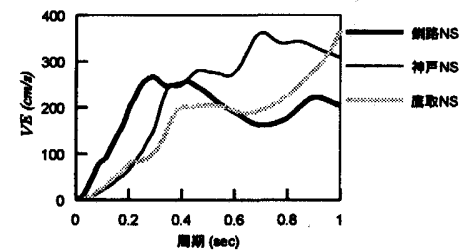

図2 入力波(NS 成分)のエネルギースペクトル
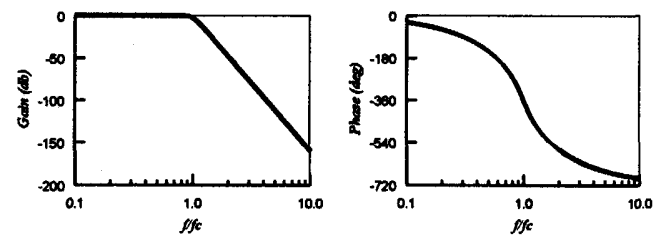

図38 次の Butterworth フィルター

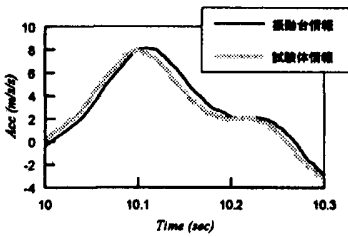

(1)補正前

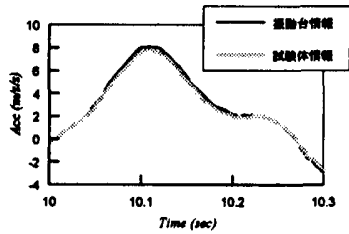

(2)補正後
因4 補正前後の加速度記録の比䡈

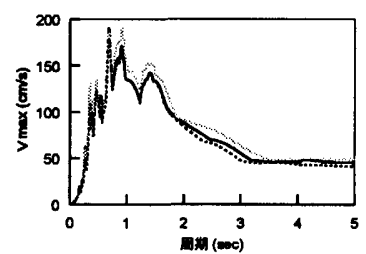

(1) $\mathrm{x}$ 方向(NS 成分) 全体

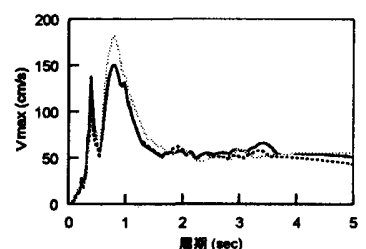

(2)y 方向(EW 成分) 全体

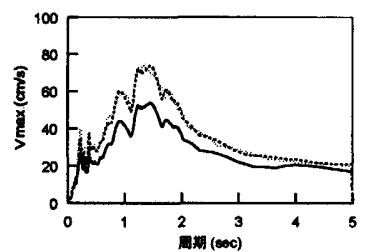

(3)z 方向(UD 成分) 全体

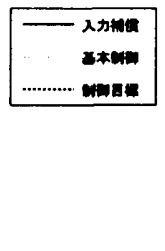

試嗝体 1 次固有周期付近桩大
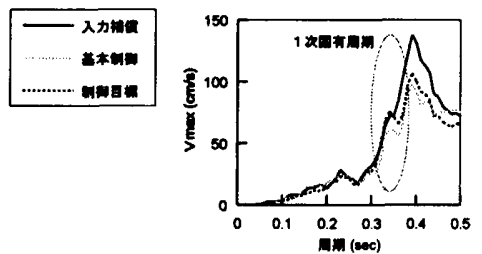

試験体 1 次固有周期付近应大
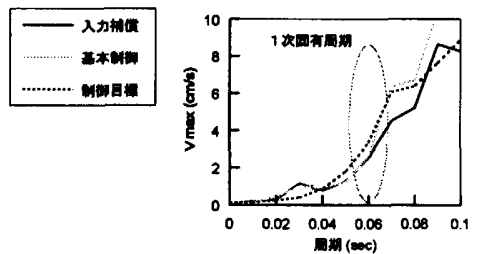

試験体 1 次固有周期付近拡大

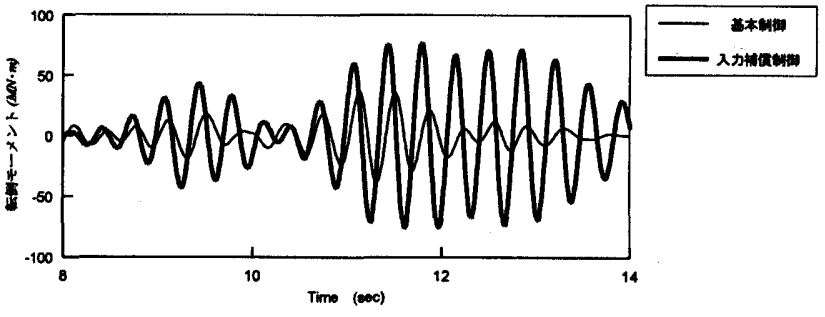

図6 転倒モーメントの時刻歴

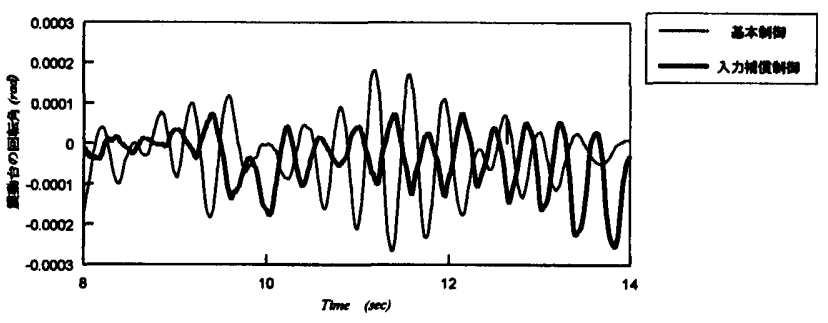

図7 辰動台に生じた回転角の時刻歷

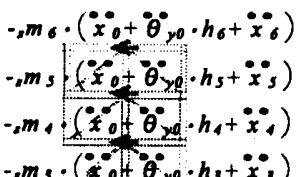

$-m s \cdot\left(\ddot{x}_{0} 0+\ddot{\theta}_{* p} \cdot h_{s}+\ddot{x}_{3}\right)$

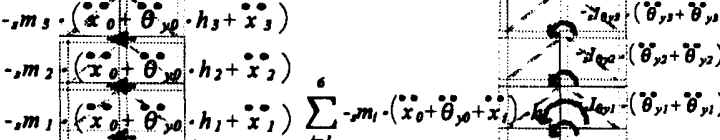

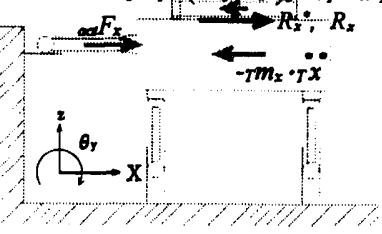

(1) $\mathrm{x}$ 方向(y 方向は同様)

(3)Z 方向

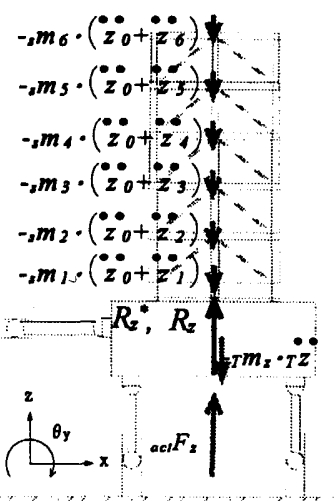

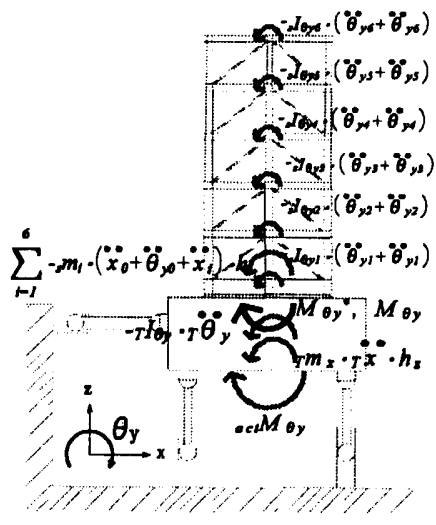

(2)y 軸周り $(x$ 軸周りは同様 $)$

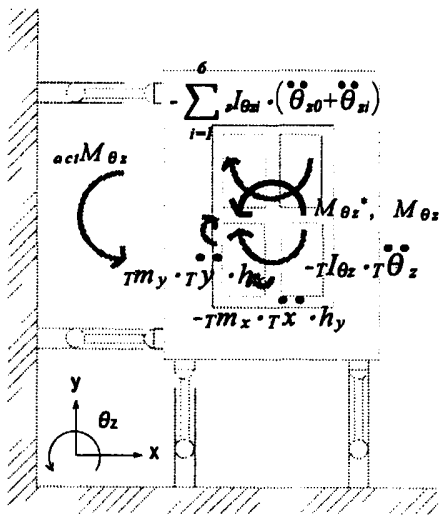

(4)Z 軸周り
図8 カとモーメントの釣り合い

図5 速度応答スペクトルの比較(减衰 2\%) 

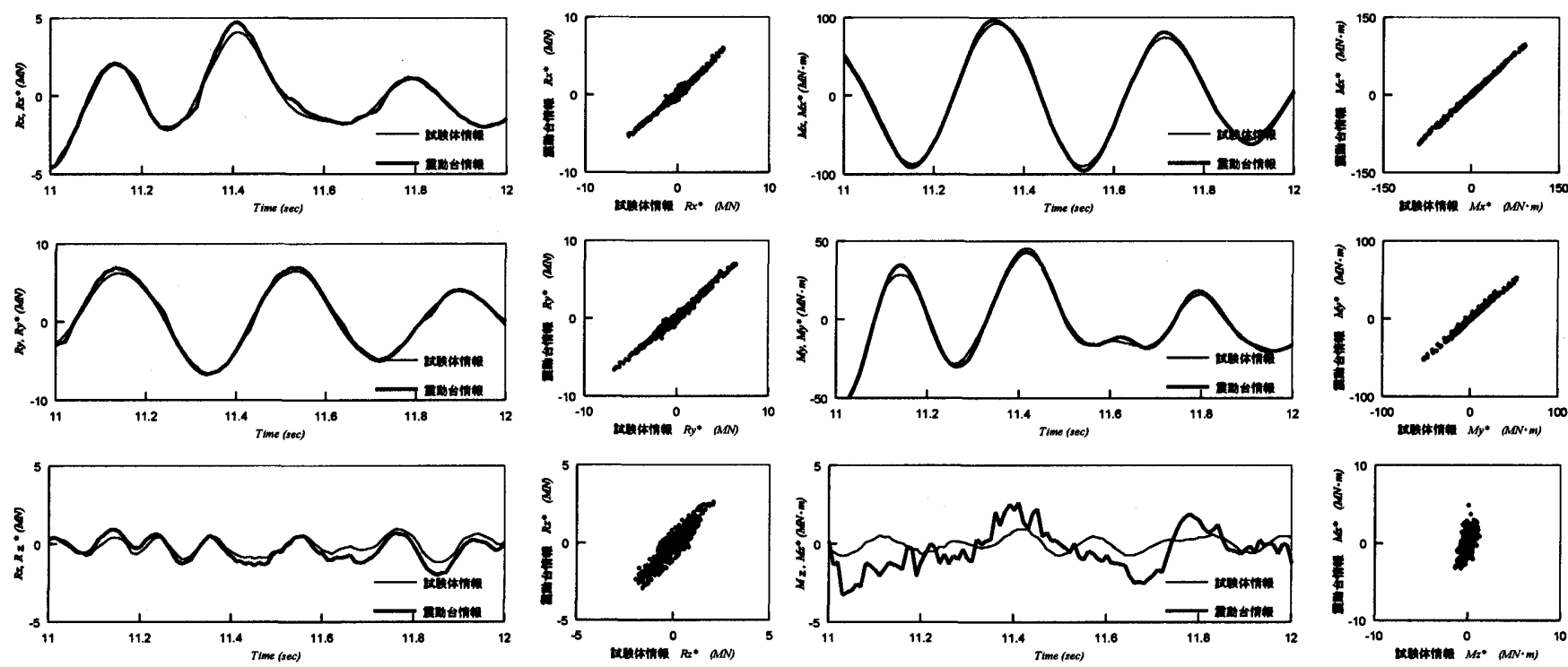

（1）弾性加振 基本制御で神戸海洋気象台記録を $90 \%$ 入力した場合
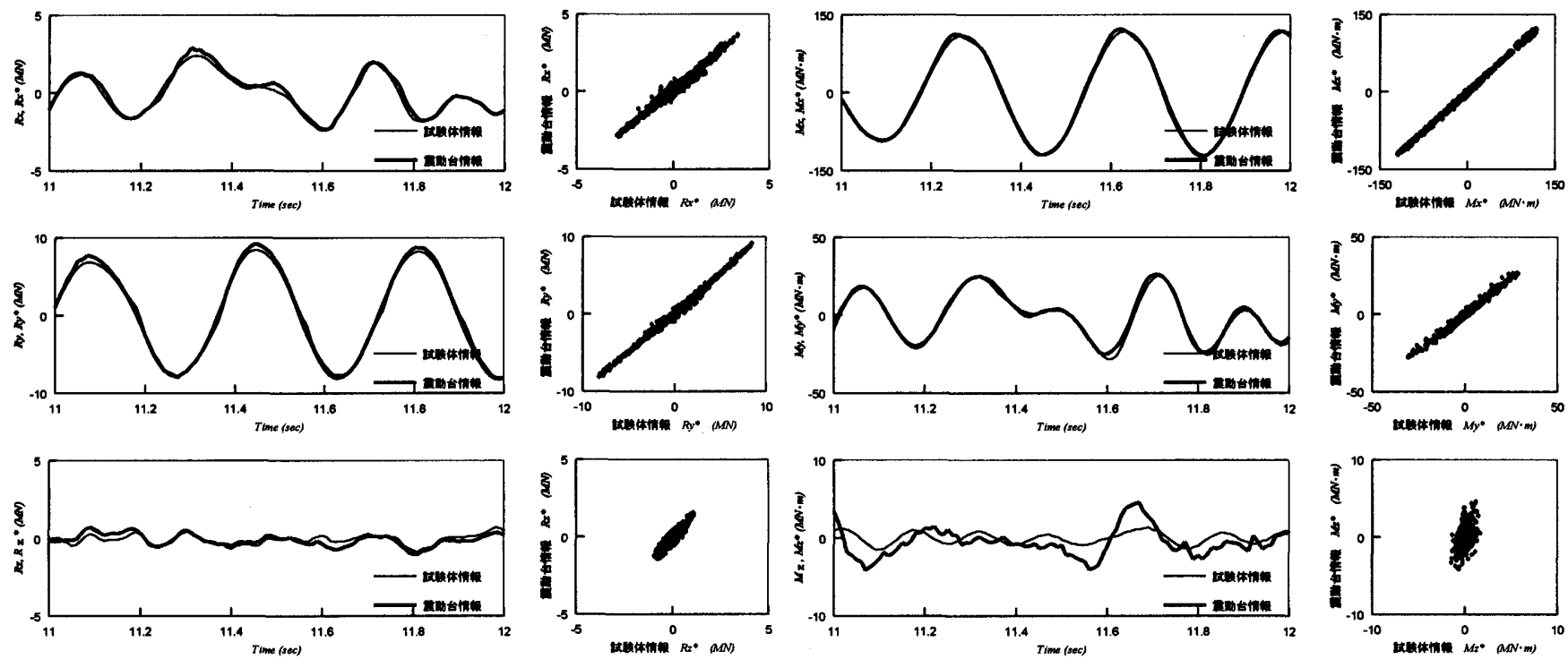

(2) 弾性加振 入力補償制御で神戸海洋気象台記録を $65 \%$ で入力した場合
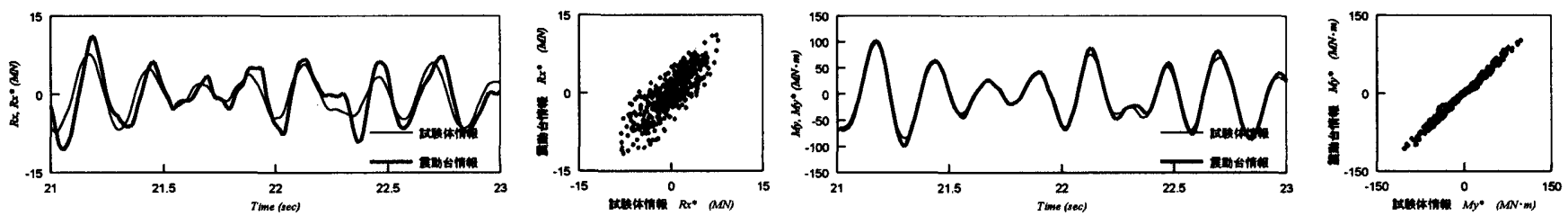

(3) 弾塑性加振 基本制御で釧路気象台記録(NS)成分を最大速度 $65 \mathrm{~cm} / \mathrm{s}$ で入力した場合
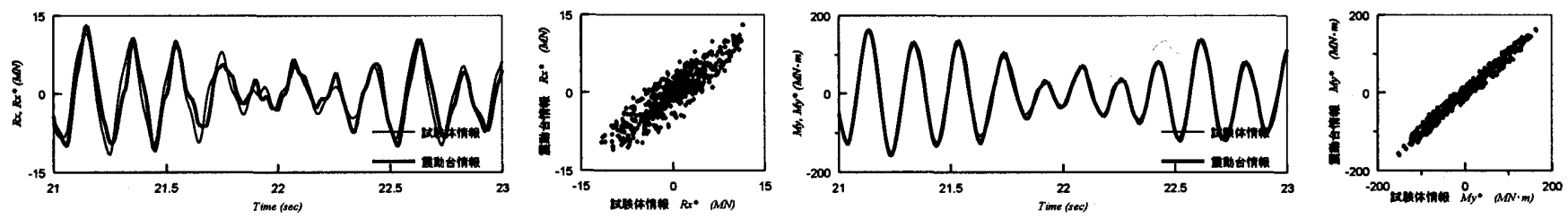

(4) 弾塑性加振 入力補償制御で釧路気象台記録(NS)成分を最大速度 $60 \mathrm{~cm} / \mathrm{s}$ で入力した場合 図9 震動台情報と試験体情報から求めた力とモーメントの比較 
式(1)〜(6)により求めた震動台情報に基づく試験体に作用した力 およびモーメントと、式(7)〜(12)により求めた試験体情報に基づく 試験体に作用した力およびモーメントを比較し、図9に示す。最大 值は概ね対応していることが分かる。しかしながら、時刻歴で見る と両者の間には不釣り合いが生じている。ここで、震動台情報は 2.4 節で述べたフィルター処理の影響を受けているが、試験体情報に補 正処理を施すことで震動台情報と位相特性を等しくした。従って、 図9における不釣り合いにはフィルター処理の影響によるものは含 まれていない。不釣り合いが生じた原因は加振機の加振力を求めた 際に、加振機内部诚衰や剛性を無視したことや継ぎ手部での摩擦の 影響によるものである。この不釣り合い力に規則性がありモデル化 できるならば、震動台情報に基づき試験体に作用した力が最大値だ けでなく時刻歴で評価できる。そこで、規則的な試験条件である正 弦波加振の結果について、不釣り合い力と振動台変位の関係をプロ ットし、図10に示す。不釣り合い力は、低周波入力時には粘性減衰 的な履歴性状を示すが、高周波入力になると異なる性状を示してお り、簡単にモデル化できるような規則性が見られない。また、この 結果には試験体の影響む含まれると考えられることから、一般性の ある不釣り合い力のモデル化については今後の検討課題とし、次節 ではこの不釣り合い力がエネルギー入力を求める際にどの程度影響 するのかを検討することにした。

\section{4. 正轩台情報に基つくエネルギー入力の汁測}

前章で述べたように、蛘動台情報に基つく試験体に作用する力と モーメントの計測結果には、加振力を加振機の差圧から直接求めた ため、加振機の剛性や内部堿衰の影響を受け試験体情報による計測 結果との間に不验り合いカが存在する。本研究では、積分結果とし ての大局的な指標であるエネルギー入力の中でこの不验り合い力の 影響がどの程度を占めるものであるかを検討する。

まず、震動台情報に基づく試験体へのエネルギー入力は、試験体 に作用するカ(モーメント)とカの作用点の変位(回転角)の力積とし て、各方向成分が式(13)〜(18)で、総エネルギー入力 $E_{\text {in }}$ iota により求まる。

$$
\begin{aligned}
& { }_{i n} E_{x}^{*}=-\int R_{x}^{*} \cdot \dot{x}_{0}^{*} d t \\
& { }_{\text {in }} E_{y}{ }^{*}=-\int R_{y}{ }^{*} \cdot \dot{y}_{0}{ }^{*} d t \\
& { }_{i n} E_{z}^{*}=-\int R_{z}^{*} \cdot \dot{z}_{0}{ }^{*} d t \\
& { }_{i n} E_{\theta x}{ }^{*}=-\int M_{\theta x}{ }^{*} \cdot \dot{\theta}_{x} \theta^{*} d t \\
& { }_{i n} E_{\theta y}{ }^{*}=-\int M_{\theta y}{ }^{*} \cdot \dot{\theta}_{y 0}{ }^{*} d t \\
& { }_{i n} E_{\theta z}{ }^{*}=-\int M_{\theta z}{ }^{*} \cdot \dot{\theta}_{z 0^{*}} d t \\
& { }_{i n} E_{\text {total }}{ }^{*}={ }_{i n} E_{x}{ }^{*}+{ }_{i n} E_{y}{ }^{*}+{ }_{i n} E_{z}{ }^{*}+{ }_{i n} E_{\theta x}{ }^{*}+{ }_{i n} E_{\theta y}{ }^{*}+{ }_{i n} E_{\theta z}{ }^{*}
\end{aligned}
$$

ここで、 $\dot{x}_{0^{*}}, \dot{y}_{0^{*}}, \dot{z}_{0^{*}}$ は震動台上面中心位置の各方向絶対速度、 $\dot{\theta}_{x 0^{*}}$, $\dot{\theta}_{y 0^{*}}, \dot{\theta}_{z 0^{*}}$ は震動台上面中心位置における $\mathrm{x}$ 軸周り, $\mathrm{y}$ 軸周り, $\mathrm{z}$ 軸周り の角速度であり、震動台情報からエネルギー入力を求めるという目 的により、震動台情報の変位および回転角を微分して求めた值を用 いる。同様に、試験体情報に基づく試験体へのエネルギー入力も、 各方向成分が式(20)〜(25)で、総エネルギー入力 ${ }_{i n} E_{\text {total }}$ が式(26)によ り求まる。

$$
\begin{aligned}
& { }_{i n} E_{x}=-\int R_{x} \cdot \dot{x}_{0} d t \\
& { }_{i n} E_{y}=-\int R_{y} \cdot \dot{y}_{d} d t \\
& { }_{i n} E_{z}=-\int R_{z} \cdot \dot{z}_{0} d t \\
& { }_{i n} E_{\theta x}=-\int M_{\theta x} \cdot \dot{\theta}_{x o} d t \\
& { }_{i n} E_{\theta y}=-\int M_{\theta y} \cdot \dot{\theta}_{y} d t \\
& { }_{i n} E_{\theta z}=-\int M_{\theta_{z}} \cdot \dot{\theta}_{z} d t \\
& { }_{i n} E_{\text {total }}={ }_{i n} E_{x}+{ }_{i n} E_{y}+{ }_{i n} E_{z}+{ }_{i n} E_{\theta x}+{ }_{i n} E_{\theta y}+{ }_{i n} E_{\theta z}
\end{aligned}
$$

\begin{tabular}{|c|c|c|c|c|c|}
\hline & $\begin{array}{l}\text { 县量 } \\
\text { (ton) }\end{array}$ & & $\begin{array}{c}\text { 重心位置 } \\
(\mathrm{cm})\end{array}$ & & 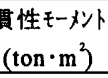 \\
\hline$T m_{x}$ & 1294.05 & $h x$ & -45.4 & $I x$ & 38540 \\
\hline$\tau m_{y}$ & 1294.05 & $h y$ & -59.5 & $I_{y}$ & 24460 \\
\hline$T m_{2}$ & 1566.85 & $h_{z}$ & -287.4 & $I_{z}$ & 55450 \\
\hline
\end{tabular}

\begin{tabular}{|c|c|c|c|c|c|c|}
\hline 階 & $R(6)$ & 5 & 4 & 3 & 2 & 1 \\
\hline$s m_{i}(\operatorname{ton})$ & 85.6 & 81.7 & 81.6 & 84.4 & 91.8 & 132.6 \\
\hline$h_{i}(\mathrm{~m})$ & 19.9 & 16.2 & 12.5 & 8.8 & 5.1 & 1.4 \\
\hline$\Delta I \theta x i\left(\operatorname{ton} \cdot \mathrm{m}^{2}\right)$ & 1107 & 1066 & 1073 & 1118 & 1217 & 2335 \\
\hline$I \theta_{i}\left(\right.$ ton $\left.\cdot \mathrm{m}^{2}\right)$ & 639 & 616 & 622 & 650 & 707 & 1474 \\
\hline$I \theta_{z i}\left(\operatorname{ton} \cdot \mathrm{m}^{2}\right)$ & 1696 & 1619 & 1633 & 1718 & 1887 & 2484 \\
\hline $\begin{array}{l}\text { 註)弾塑性加挹 } \\
\text { 両側の構面の }\end{array}$ & ה & a & & & & \\
\hline
\end{tabular}

表2 鹿動台可動部に関するデーター

ここで震動台可動部質量には、下に例示するように他の 軸のリンク材(下図では $\mathrm{Z}$ 軸)の質量の $1 / 3$ を考虑した。

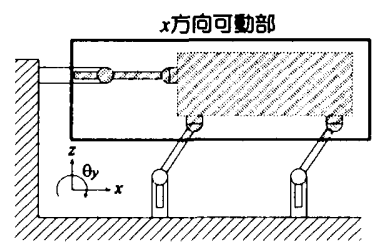

表3 試験体に関するデーター

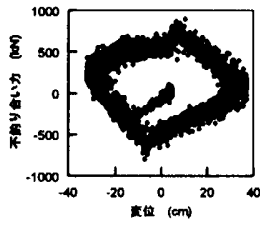

$\mathrm{X}$ 軸 $0.5 \mathrm{~Hz}$

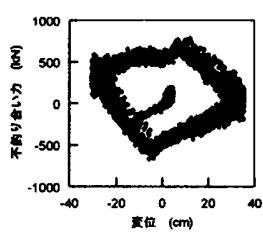

$\mathrm{Y}$ 軸 $0.5 \mathrm{~Hz}$

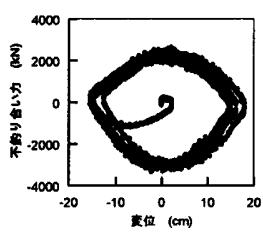

$\mathrm{Z}$ 軸 $0.5 \mathrm{~Hz}$

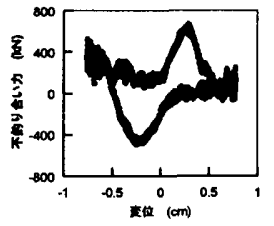

$X$ 軸 $3 \mathrm{~Hz}$

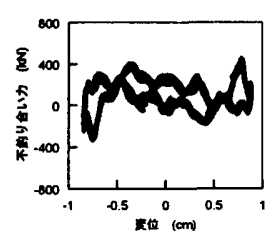

$\mathrm{Y}$ 軸 $3 \mathrm{~Hz}$

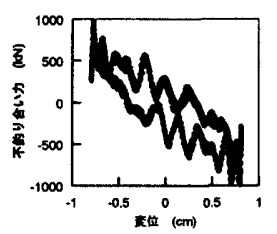

$\mathrm{Z}$ 軸 $3 \mathrm{~Hz}$

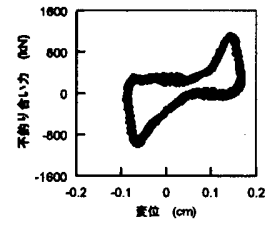

$\mathrm{X}$ 軸 $7 \mathrm{~Hz}$

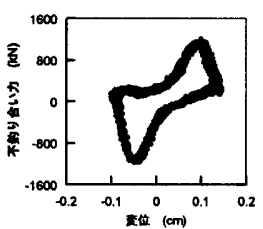

$\mathrm{Y}$ 軸 $7 \mathrm{~Hz}$

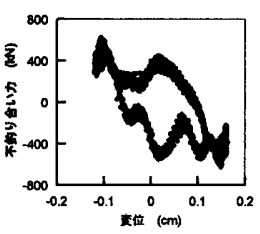

$\mathrm{Z}$ 軸 $7 \mathrm{~Hz}$
図10 正弦波加振(基本制御)での不釣り合い力 


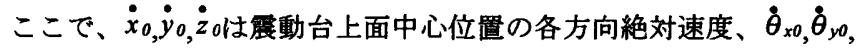
$\dot{\theta}_{z 0}$ は震動台上面中心位置における $\mathrm{x}$ 軸周り, $\mathrm{y}$ 軸周り, $\mathrm{z}$ 軸周りの角 速度であり、台上両端部に設置した加速度計による上下方向の計測 値をセンサー間距離で除して角加速度を求め、これを積分した値で ある。

各加振での震動台情報に基づき求めた試験体への総エネルギー入 力 ${ }_{i n} E_{\text {toda }}$ と、試験体情報に基づき求めた試験体への総エネルギー入 力in $E_{\text {totad }}$ を比較し、図11(1)に示す。in $E_{\text {total }}$ については、キャリブレー ションのため、試験体各層に作用した力と各層に生じた層間変形の 増分を積分して求めた試験体の吸収エネルギー ${ }^{2} E_{\text {total }}$ とも比較し、 図11 (2) に示す。in $E_{\text {totad }}$ とd $E_{\text {btall }}$ は良い対応を示しており、試験体情報 に基づき試験体への総エネルギー入力が正しく計測できていること がわかる。一方、震動台情報に基づく総エネルギー入力の計測結果 は試験体情報に基づく結果を大きく上回っており、加振力を求める 際の誤差の影響が大きいことがわかる。また、入力が大きくなると 制御方法による違いも見られ、試験体の影響も受けていると考えら れる。震動台情報に基づき求めた総エネルギー入力における誤差の 評価は、これから蓄積されていく実駼結果や加振力の計測方法と併 せて、今後総合的に検討を進める必要がある。

\section{5. エネルギー入カの钼点による制御方法の評価}

前章で述べたように、現段階では震動台情報から試験体へのエネ ルギー入力を正しく計測することはできなかった。しかしながら、

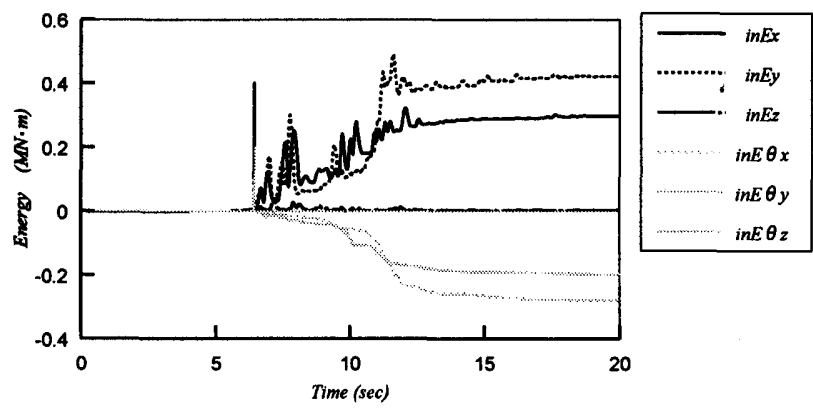

(1)弾性加振 基本制御で神户海洋気象台記録を 90\%で入力した場合

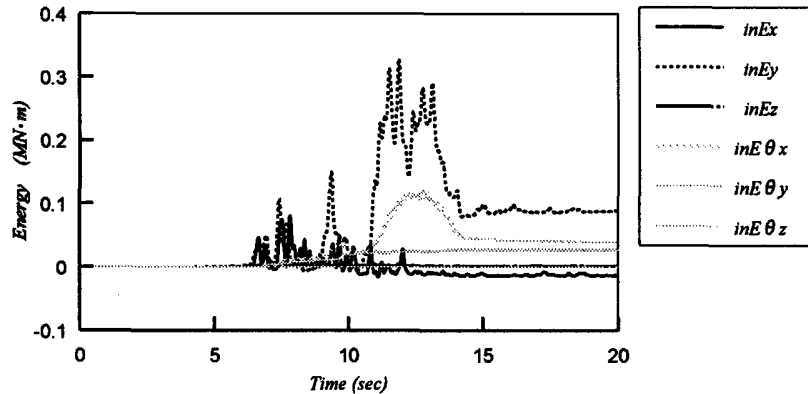

(2)弾性加振 入力補償制御で神戸海洋気象台記録を $65 \%$ で入した場合
試験体情報からはエネルギー入力は計測できていたことから、試験 体情報に基づく試験体へのエネルギー入力の計測結果を用いて、制 御手法の違いにより実験にどのような影響が出たかを検討する。弾 性加振および弾塑性加振における試験体への各方向成分のエネルギ 一入力の時刻歴を、図12に示す。基本制御で加振した場合、水平成 分により入力したエネルギーの大部分が台の回転により逸散してい る。一方入力補償制御で加振した場合には、水平成分によるエネル ギー入力だけでなく、台の回転でも大量のエネルギーが試験体に投 入されている。基本制御・入力補償制御のいずれの場合においても、 一般的な地震入力としては存在しない回転成分により、試験体に対 する外乱の効果が目標とは大きく異なるものとなっていることが端 的にわかる。波形や応答スペクトルからは捉えにくい現象が、エネ ルギー入力の観点で明確に捉えることができた。

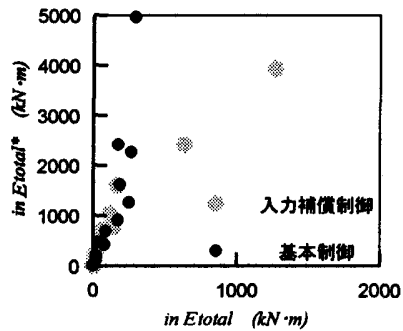

(1) ${ }_{\text {in }} E_{\text {total }}{ }^{*}$ と ${ }_{i n} E_{\text {totad }}$ の比較

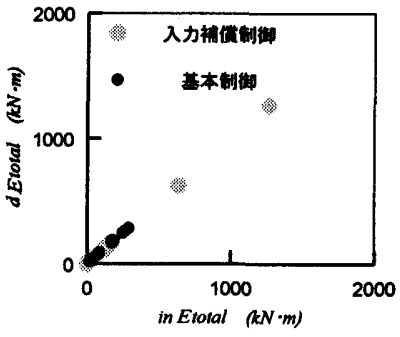

(2)d $E_{\text {total }}$ と ${ }_{i n} E_{\text {total }}$ の比較
図11 総エネルギー入力の計算值の比較
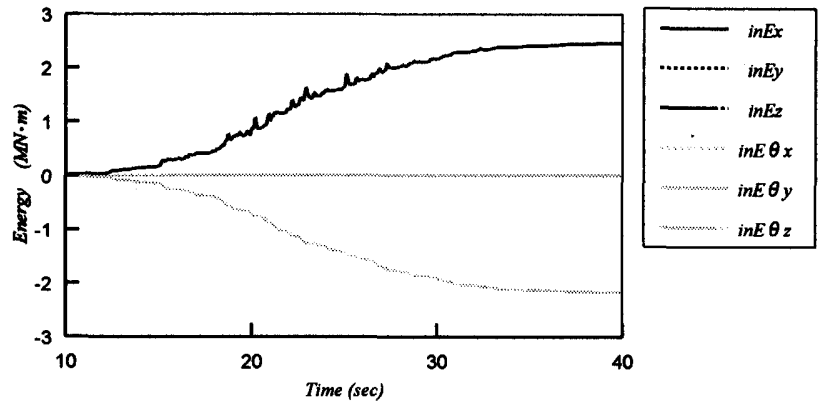

(3) 弹塑性加振 基本制御で釧路気象台記録(NS)成分を 最大速度 $65 \mathrm{~cm} / \mathrm{s}$ で入力した場合

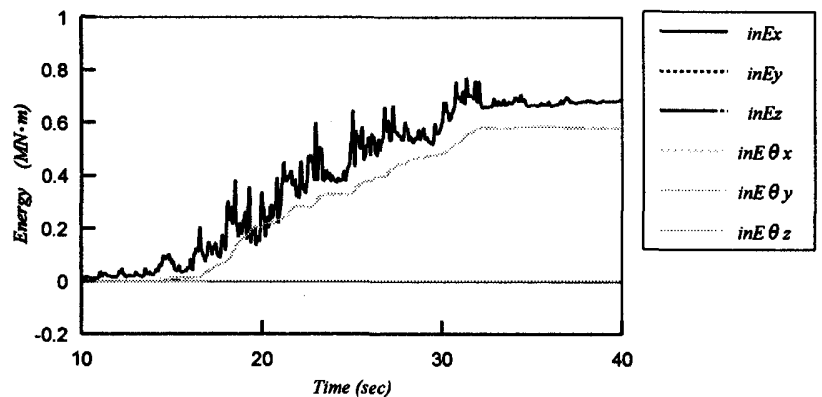

(4) 弾塑性加振 入力補償制御で釧路気象台記録(NS)成分を 最大速度 $60 \mathrm{~cm} / \mathrm{s}$ で入力した場合

図12 エネルギー入力の時刻歴の比較 


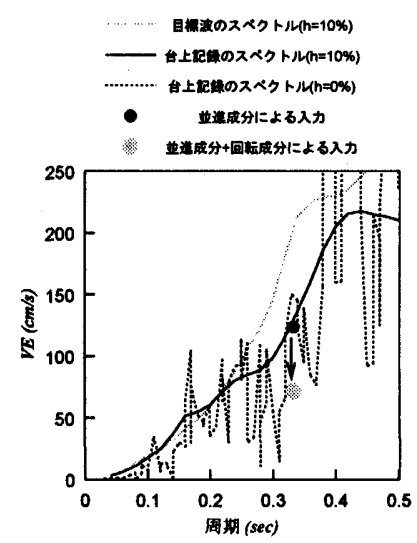

(1)弾性加振 基本制御

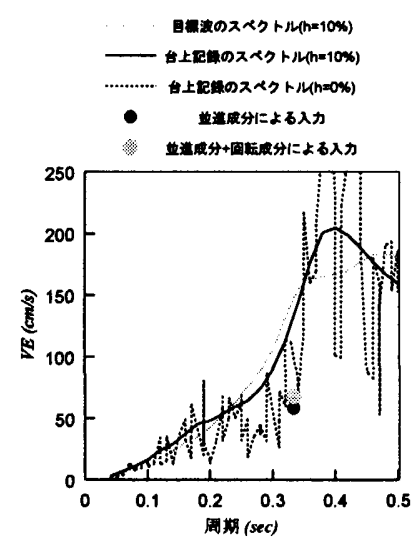

(2)弹性加振 入力補谟制御

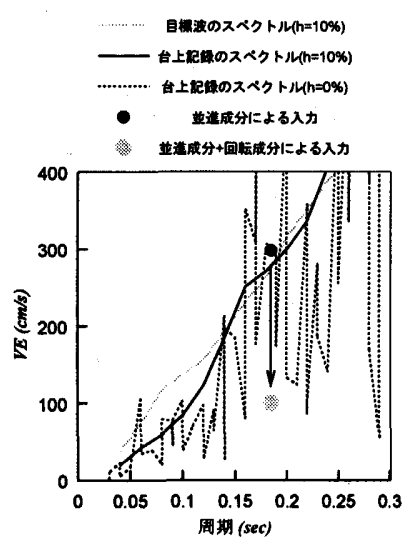

(3)弹塑性加振 基本制御

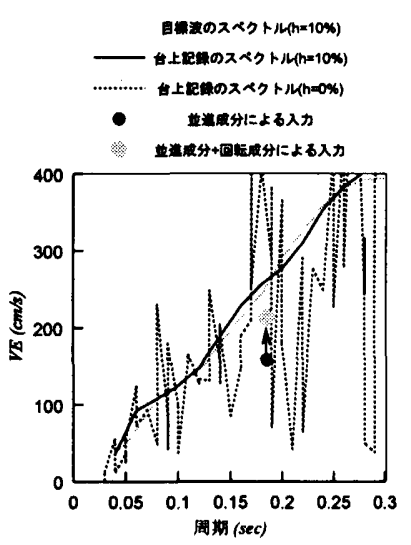

(4)弾塑性加振 入力補傥制御
図13 エネルキーースペクトルとエネルギー入力の速度换算値

試験体に入カされたエネルギーを、エネルギースペクトル上で検 討する。図13に弾性加振については $\mathrm{y}$ 方向、弾塑性加振については $\mathrm{x}$ 方向について、入力目標波のエネルキースペクトル(减衰 $10 \%$ )と台 上記録のエネルギースペクトル(堿衰 $10 \%$ と減衰 $0 \%$ )を描き、これ に並進成分による試験体へのエネルギー入力の速度換算值(弾性加 振の場合 $\sqrt{2_{i n} E_{y} / M}$ 、弾塑性加振の場合 $\sqrt{2_{i n} E_{\searrow} / M}$ 、Mは試跧体総質 量)を○で、並進成分と回転成分による試験体へのエネルギー入力 の速度換算値(弾性加振の場合 $\sqrt{2\left({ }_{i n} E_{y}+{ }_{i n} E_{\theta x}\right) M}$ 、弹塑性加振の場合 $\left.\sqrt{2\left({ }_{i n} E_{x}+{ }_{i n} E_{\theta_{y}} \gamma M\right.}\right)$ を ペクトルにおける目標波と台上記録の差は、制御による並進成分の 入力の誤差である。また、台上記録について堿衰 $0 \%$ のネルギー スペクトルを描いたのは、弾性加振はもちろんのこと、弾塑性加振 においても試験体の塑性化の程度は極わずかであり、エネルギー入 力量は減衰 $0 \%$ 弾性系に近いと考えたことによる。並進成分によ るエネルギー入力は、台上記録减衰 $0 \%$ のエネルギースペクトル上 にほぼプロットされており、回転による影響はプロットのずれとし て見て取れる。これらの結果からも、基本制御の場合、水平成分の エネルギーが回転方向に逸散していることがわかる。なお、弾塑性 加振入力補償制御の場合、並進成分の入力が小さいように見えるが、 これは一部の座屈拘束ブレースが塑性化したため長周期化したもの の、1 次固有周期より長周期側の入力が小さかったことにより、並 進成分によるエネルギー入力も小さくなったと考えられる。

\section{結論}

1.震動台制御情報に含まれる加振機の圧力情報から加振力を求め、 これを用いて試験体に作用したカとモーメントを求めたところ、試 験体側での計測結果と最大值は概ね对応した。

2.震動台制御情報に基づく試験体に作用した力とモーメントと、試 験体側での計測結果を時刻歴で比べると、全体的な挙動は概ね捉え られたものの、不釣り合いが生じていた。不釣り合いの原因は、加 振力を求める際に加振機の内部堿衰や剛性を無視したことや継ぎ手 部での摩擦の影響によるものであるが、正弦波加振の結果からは简 単にモデル化できるような規則性は見られなかった。

3.積分結果としての大局的な指標であるエネルギー入力の中で、震 動台情報に基づく試験体に作用するカとモーメントに含まれる不釣 り合いの影響がどの程度を占めるものであるかを検討したところ、 不验り合いの影響が支配的であり、震動台情報に基づく試験体への エネルギー入力の計測が現状ではできないことがわかった。

4.試験体情報に基づく試験体へのエネルキー入力の計測結果を用い て制御手法の連いによりどのような影響が出たかを検討したとこ ろ、基本制御で加振した場合には、水平成分により入力されたェネ ルギーの大部分が台の回転により逸散し、入力補傥制御で加㧐した 場合には、水平成分によるエネルギー入力だけでなく、台の回転で も大量のエネルギーが試験体に投入されていることがわかった。 5.試験体に作用した力を試験機側から計測することは、実験を行う 上で重要であり、加振機内部の减衰や剛性などを正確に評価したモ デルの楎築により加振力を正確に計測できるようにすること、そし て、試耠体へのエネルギー入力を制御情報より計測できるようにす ることは今後解決すべき課題である。

6.大きな転倒モーメントが作用した際に、台に回転が生じると実験 結果への影響が大きいことから、回転を成るだけ発生させないよう に制御手法を向上させる必要がある。

\section{韵辞}

本論文は、「振動台エネルギー入力に関する検討会:秋山 宏(日大), 阿部健一(防災科研), 小川信行(元防災科研), 甲斐芳郎(清水建設), 加 藤 敦(防災科研), 坂下克之(元防災科研), 森 利弘(元防災科研), 山田 哲(東工大)，山野祐司(日建設計)」による成果の一部を取り䋸めた ものである。性能確認試験においては、中島正愛センター長をはじ めとする E-Defense 関係者、東京農工大田川研究室ほか、多くの方 のご協力をいただいた。ここに記して感謝の意を表す。

\section{考文献}

1)秋山 宏: 建築物の耐展極限設計, 東京大学出版会, 1980. 2)高圧ガス保安協会振動実験専門委員会 : 鋼製開底円筒形賍槽の耐震実駼報 告(第 1 回)/(第 2 回), 高圧ガス, Vol.21, No.7/No.8, pp.363-373/440-452, 1984, 高圧ガス, Vol.21, No.7, pp.363-373, 1984

3)中村 豊, 上半文昭, 井上英司：1995 年兵庫県南部地震の地震動記録波形と 分析(II), JR 地震情報 No.23d, 財団法人鉄道総合技術研究所ユレダス開発推 准部, 1996.3

4)気象庁 87 型電磁式強震計波形データーによる

5)鹿岛俊英，北川良和: 平成 5 年(1993 年)釧路沖地展強震観测記録速報，建設 省建築研究所, 1993.2 